\title{
PEMANFAATAN UMBI GANYONG SEBAGAI BAHAN BAKAR ALTERNATIF BIOETANOL
}

\author{
Kms. Ridhuan, Ahmad Sukamto \\ Program Studi Teknik Mesin Fakultas Teknik Universitas Muhammadiyah Metro \\ Jl. KH. Dewantara No. 116 Metro Telp. (0725) 45932 - 42445 Kode Pos 34111 \\ kmsridhuan@yahoo.co.id
}

\begin{abstract}
Abstrak : Pengembangan energi merupakan hal yang mendesak untuk zaman sekarang ini. Salah satu sumber energi alternatif yang potensial yaitu umbi ganyong yang dapat diolah sebagai bahan bakar bioetanol. Bioetanol merupakan bahan bakar pengganti bensin yang dapat diolah dari bahan tumbuh - tumbuhan. Umbi ganyong cukup baik karena kandungan patinya cukup tinggi. Penelitian ini bertujuan untuk mengetahui proses pengolahan umbi ganyong menjadi bioetanol pada proses penyulingan dengan kapasitas bioetanol yang dihasilkan dari umbi ganyong yang yang digunakan.

Proses pengolahan umbi gayong dilakukan mulai dari pencucian, lalu umbi gayong digiling atau di parut menjadi bubur tepung, kemudian diperas dan menghasilka pati. Selanjutnya pati ditambah air lalu direbus (proses liquifikasi) kemudian dilanjutkan proses sakarifikasi. Setelah itu dikasih ragi untuk proses fermentasi. Lalu proses akhir pada penyulingan dengan destilasi untuk mendapatkan minyak bioetanol.

Dari umbi ganyong sebanyak $45 \mathrm{~kg}$ menghasilkan pati $8,3 \mathrm{~kg}$, pati tersebut ditambah air sebanyak 27 liter, sehingga menjadi 35,3 liter. Selanjutnya pati direbus untuk proses liquifikasi selama 30 menit dengan suhu $105{ }^{\circ} \mathrm{C}$ dan dilanjutkan proses sakarifikasi selama 75 menit dengan suhu $95{ }^{\circ} \mathrm{C}$. Setelah selesai turunkan suhu hingga $40{ }^{\circ} \mathrm{C}$ dan ditambahkan ragi untuk difermentasi selama 7 hari. Proses penyulingan (distilasi) dengan suhu $78{ }^{\circ} \mathrm{C}$. Hasil dari penyulingan mendapatkan bioetanol sebanyak 3,15 liter.
\end{abstract}

Kata Kunci : Ganyong, energi, bioetanol

\section{Pendahuluan}

Pada masa sekarang ini pemakaian bahan bakar sangat tinggi, sementara sumber bahan bakar minyak bumi yang tersedia mulai menipis, akibatnya harga bahan bakar minyak bumi terutama bensin menjadi mahal. Oleh karena itu, perlu adanya pengembangan energi alternatif untuk menanggulangi permasalahan ini. Salah satu sumber bahan baku yang cukup potensial yaitu umbi ganyong sebagai bahan bakar bioetanol.

Bioetanol merupakan bahan bakar alternatif untuk kendaraan bermotor yang menggunakan bahan bakar bensin, penggunaannya pada kendaraan bisa dengan Bioetanol murni tanpa campuran khusus mesin modifikasi dan dapat dicampur dengan bensin. Bioetanol adalah etanol yang diproduksi dengan cara fermentasi menggunakan bahan baku tanaman.

Ganyong merupakan salah satu tanaman yang banyak tumbuh disekitar kita, tetapi pemanfaatannya sangat kurang. Ganyong dengan nama latin Canna edulis kerr ini sangat berpotensi untuk dimanfaatkan sebagai bahan bakar alternatif Bioetanol, karena kandungan 
pati pada umbinya cukup tinggi dan dapat dimanfaatkan sebagai sumber penghasil Bioetanol. Ganyong adalah tanaman jenis umbi - umbian yang kurang populer dibandingkan jagung, singkong, ubi jalar dan sejenisnya,

Proses pemanfaatannya, umbi yang dipisahkan antara pati dan ampas umbi ganyong, pati yang diperoleh dilakukan proses liquifikasi dan sakarifikasi lalu difermentasikan tanpa oksigen (anaerob). Setelah fermentasi, dilakukan penyulingan untuk menghasilkan Bioetanol. Untuk mempercepat proses fermentasi digunakan bahan tambah ragi (saccharomyces cerevisiae). Ragi adalah jamur yang terdiri dari satu sel. Reproduksi dengan membentuk tunas, dan sangat baik untuk meningkatkan pertumbuhan mikroba pada saat proses fermentasi.

Umbi ganyong ini sangat baik untuk dimanfaatkan sebagai bahan baku pembuatan bioetanol, karena tanaman ini mampu tumbuh disekitar masyarakat, dan masyarakat saat ini kurang memanfaatkannya, umbi ganyong ini memiliki kadar pati seperti tanaman jagung, singkong, umbi jalar, dan sejenisnya, yang mempunyai nilai harga jual tinggi dipasaran. Tetapi tanaman ganyong ini memiliki kesulitan dalam pertumbuhannya, diantaranya tanaman ini merupakan tanaman dua musim yang tumbuh cukup lama.

\section{LANDASAN TEORI}

\subsection{Bioetanol}

Bioetanol adalah etanol yang diproduksi dengan cara fermentasi menggunakan bahan baku nabati. Sedangkan etanol adalah senyawa organik golongan alkohol yang mengandung gugus hidrolis. Etanol dapat diklasifikasikan berdasarkan bahan baku yang digunakan, proses, dan pemanfaataannya.

a) Klasifikasi berdasarkan bahan baku serta prosesnya.

1) Etanol Nabati: secara mikrobiologis menggunakan bahan baku berpati (jagung, ubi kayu, ganyong, dan umbi - umbian lain), serta bahan yang mengandung gula (molases, tebu, aren, dan lainnya), dan bahan berserat (onggok, jerami, tongkol jagung, dan lain lain)

2) Etanol Sintesis : secara sintesis menggunakan bahan baku antara lain minyak mentah, gas. Saat ini produksi etanol sintesis kurang dari $5 \%$ dari total produksi.

b) Klasifikasi berdasarkan kandungan air

1) Etanol (95 - 96) \% (Alkohol prima super, Prima I, dan Prima II)

2) Etanol 99,5\% (anhydrous etanol) dengan kandungan air 0,05\%

c) Klasifikasi menurut pemanfaatannya.

1) Menurut industri (industrial grade), sebagai pelarut pada pembuatan vernis, minyak wangi, iodium tincture dan spirtus; di laboratorium sebagai pelarut senyawa bersifat polar; dibidang kedokteran sebagai bahan baku pembuatan khloroform, iodoform.

2) Untuk minuman beralkohol (portable grade)

3) Untuk bahan bakar ( Fuel grade etanol ) (Nur Rinchana : 2011).

Pengembangan bioetanol oleh pemerintah Indonesia pada tahap awal difokuskan dari bahan baku umbi kayu. Namun demikian, dengan semakin banyaknya produk yang menggunakan ubi 
kayu atau singkong. Pengembangan selanjutnya perlu dipikirkan untuk menggunakan bahan baku lain yang lebih murah dan mudah didapat, diantaranya dari umbi - umbian lain yaitu : ubi jalar, ganyong, garut. (Nur Rinchana. : 2011)

\subsection{Umbi Ganyong}

Ganyong adalah tanaman yang cukup potensial sebagai sumber karbohidrat. Selain dapat digunakan untuk penganekaragaman menu rakyat, juga mempunyai aspek yang penting sebagai bahan dasar industri.

Ganyong (Canna Edulis Kerr) adalah tanaman herba yang berasal dari Amerika Selatan. Rhizoma atau umbinya bila sudah dewasa dapat dimakan dengan mengolahnya terlebih dahulu, atau untuk diambil patinya.

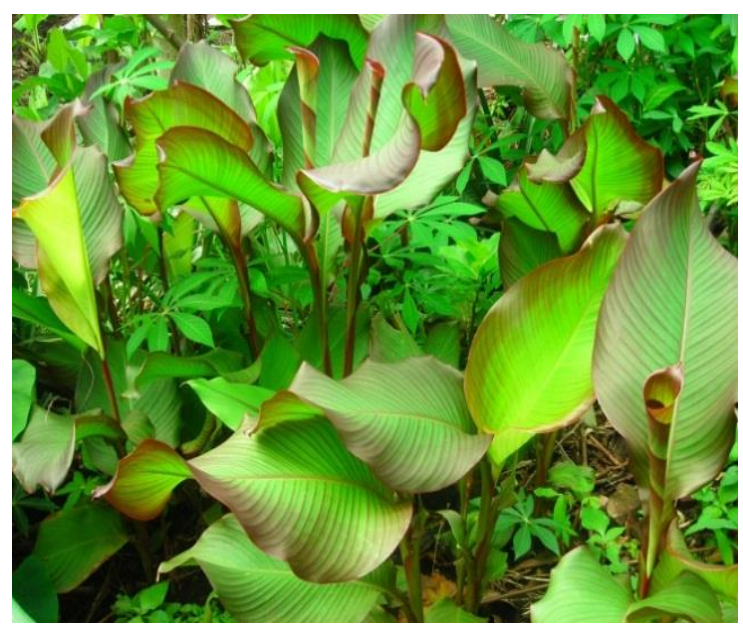

Gambar 1. Tanaman Ganyong.

Umbi ganyong memiliki kandungan gizi dan kandungan pati yang cukup tinggi bila dibandingkan sumber sumber makanan lainnya seperti jagung dan ubi kayu yang memiliki nilai jual. Dalam tabel 2.1 dibawah ini dijelaskan setiap 100 gram umbi ganyong memiliki kandungan gizi sebagai berikut :
Tabel 1. Kandungan Gizi pada ganyong setiap 100 Gram

\begin{tabular}{|l|l|c|}
\hline No & \multicolumn{1}{|c|}{ Gizi } & Kadar \\
\hline 1 & Kalori & $95 \mathrm{kal}$ \\
2 & Protein & $1 \mathrm{grm}$ \\
3 & Lemak & $0,11 \mathrm{grm}$ \\
4 & Karbohidrat & $22,6 \mathrm{grm}$ \\
5 & Vitamin B1 & $10,1 \mathrm{mg}$ \\
6 & Vitamin C & $10 \mathrm{mg}$ \\
7 & Kalsium & $21 \mathrm{mg}$ \\
8 & Fosfor & $70 \mathrm{mg}$ \\
9 & Zat besi & $1,9 \mathrm{mg}$ \\
10 & Air & $75 \mathrm{grm}$ \\
11 & BBD & $65 \%$ \\
\hline \multicolumn{2}{|c|}{ (Sumber : Direktorat Gizi Depkes RI, 1981) }
\end{tabular}

\subsection{Bahan Tambah Ragi}

Ragi atau yeast (Saccharomyces Cerevisiae) merupakan organisme bersel tunggal. Berkembang biak dengan membelah diri. Berbeda dengan bakteri, yeast memiliki ukuran sel lebih besar (sekitar 10x), memiliki organ - organ, memiliki membran inti sel, dan DNA terlokalisasi di dalam kromosom dalam inti sel. Ini menyebabkan yeast bisa melakukan fungsi - fungsi sel yang berbeda - beda di tiap lokasi dalam selnya. Singkatnya, sel yeast lebih mirip sel organisme tingkat tinggi seperti hewan.

\subsection{Alat Yang Digunakan}

Pada proses pembuatan bioetanol diperlukan beberapa rangkaian alat atau komponen, adapun komponen utama yng digunakan adalah :

a) Tabung Ketel

Pada proses perebusan ketel sangat diperlukan untuk proses liquifikasi, sakarifikasi, dan distilasi. Ketel bioetanol merubah air menjadi uap dengan cara dipanaskan. Pemanasan atau perebusan sampai temperatur 
$78{ }^{\circ} \mathrm{C}$. Hal ini karena alkohol akan menguap pada temperatur $78{ }^{\circ} \mathrm{C}$.

b) Tabung Distilasi

Distilasi adalah suatu cara pemisahan larutan dengan menggunakan panas menggunakan pemisah. Prinsip kerjanya, zat cair yang memiliki titik didih berbeda dipanaskan agar salah satu dari zat cair tersebut dapat berubah menjadi uap. Uap tersebut dialirkan melalui pipa yang dihubungkan dari ketel perebusan ke tabung penyulingan atau distilasi. Uap yang mengalir didalam pipa didinginkan agar menjadi cair kembali. Media untuk mendinginkan menggunakan air. karena air dapat menyerap dan melepaskan panas cukup baik.

\subsection{Proses Pengolahan}

Proses pembuatan bioetanol dengan cara fermentasi sangat dipengaruhi oleh bahan baku yang digunakan. Proses ini terbagi menjadi dua yaitu :

a) Proses hulu: bahan baku diproses menjadi gula dan difermentasi menghasilkan alkohol.

b) Proses hilir: distilasi dari hasil fermentasi, kemudian dehidrasi atau pemurnian menjadi etanol (95\%99,5\%).

diagram proses bioetanol dari bahan baku sumber gula, seperti tetes tebu dan nira, lebih sederhana dan mudah karena bisa langsung fermentasi. Pada bahan sumber pati harus dilakukan pengolahan awal liquifikasi-1. Sedangkan pada sumber serat dilakukan pengolahan awal diliquifikasi, kemudian sarifikasi-2.

Dalam proses pembuatan bioetanol yang menggunakan bahan berpati, untuk mempermudah proses pengolahannya maka menggunkan beberapa proses menurut (Nur Rinchana : 2011) : a) Proses penggilingan

Penggilingan merupakan suatu proses dalam pengolahan bioetanol dari umbi untuk mempermudah pada proses pemisahan antara pati dengan ampas umbi.

b) Proses Liquifikasi

Pembuatan ubi kayu dilakukan pada tangki pencampuran. Cara yang dilakukan adalah dengan mencampurkan pati sebanyak sepertiga kali jumlah air dan diaduk sampai homogen. Dengan temperatur $105^{\circ} \mathrm{C}$ selama 30 menit.

c) Proses Sakarifikasi

Pada proses sakarifikasi yaitu pati yang telah terdegradasi menjadi dekstrin, selanjutnya diturunkan suhunya dari $105^{\circ} \mathrm{C}$ menjadi $95{ }^{\circ} \mathrm{C}$. Selanjutnya di sakarifikasi dengan penambahan enzim amiloglukosidase. Enzim ini berfungsi untuk memecah rantai dekstrin menjadi glukosa.

d) Proses Fermentasi

Proses fermentasi dimaksudkan untuk mengubah glukosa menjadi bioetanol (alkohol) menggunakan ragi. Alkohol yang diperoleh dari proses fermentasi ini, biasanya alkohol dengan kadar (8-10) \% volume. Proses fermentasi umbi ganyong selama 7 hari

e) Distilasi

Distilasi merupakan proses pemisahan campuran antara dua atau lebih cairan berdasarkan perbedaan fase antara dua cairan, yaitu volatilitas relatif dan perbedaan titik didih. Menurut Geankoplis (1983) proses distilasi dilakukan yang dilakukan pada beberapa industri dapat melibatkan dua komponen. 


\section{METODE PENELITIAN}

\section{1. Tempat dan Waktu Penelitian}

Tempat dilaksanakanya penelitian tentang pemanfaatan umbi ganyong sebagai bahan bakar alternatif bioetanol menggunakan bahan tambah ragi ini diLaboratorium Teknik Mesin di Kampus II Universitas Muhammadiyah Metro, pada bulan Juni sampai dengan September 2012.

\section{2. Alat dan bahan}

\subsubsection{Alat Yang Digunakan}

a) Ketel Perebusan.

b) Bak Fermentasi

c) Tabung Distilasi

d) Penampung hasil bioetanol

e) Gelas Ukur

f) Stop Watch

g) Thermometer

h) Timbangan

\subsubsection{Bahan}
a) Umbi ganyong
b) Ragi
c) Air

\subsection{Persiapan Pembuatan Bioetanol}

a) Umbi ganyong dicuci dan dikeringkan lalu ditimbang

b) Setelah itu Umbi ganyong digiling

c) Kemudian diperas, lalu pisahkan ampas umbi dan pati ganyong, d) Hasil pemisahan masih berupa air yang berwarna putih, lalu endapkan selama semalam.

e) Setelah mengendap pati umbi keringkan lalu ditumbuk dan diayak untuk memperoleh pati yang benar - benar lembut, agar pada proses liquifikasi pati ganyong dapat bercampur secara homogen.

\section{4. Proses Pembuatan Bioetanol}

\subsubsection{Proses Hulu}

a) Tahap liquifikasi ini dilakukan dengan cara memasukan pati ganyong yang telah dihaluskan ke dalam ketel, banyaknya pati adalah $8,3 \mathrm{~kg}$ dengan volume air 3 kali dari berat pati yaitu 25 liter air. Aduk agar pati dan air dapat tercampur secara homogen.

b) Tahap sakarifikasi yaitu Panaskan ketel hingga temperatur $105{ }^{\circ} \mathrm{C}$ selama 30 menit, lalu turunkan temperatur hingga $95{ }^{\circ} \mathrm{C}$ selama 75 menit. Proses ini bertujuan untuk memecahkan rantai dekstrim menjadi glukosa. Setelah tahap ini selsai maka dilakukan penurunan temperatur hingga mencapai $40{ }^{\circ} \mathrm{C}$.

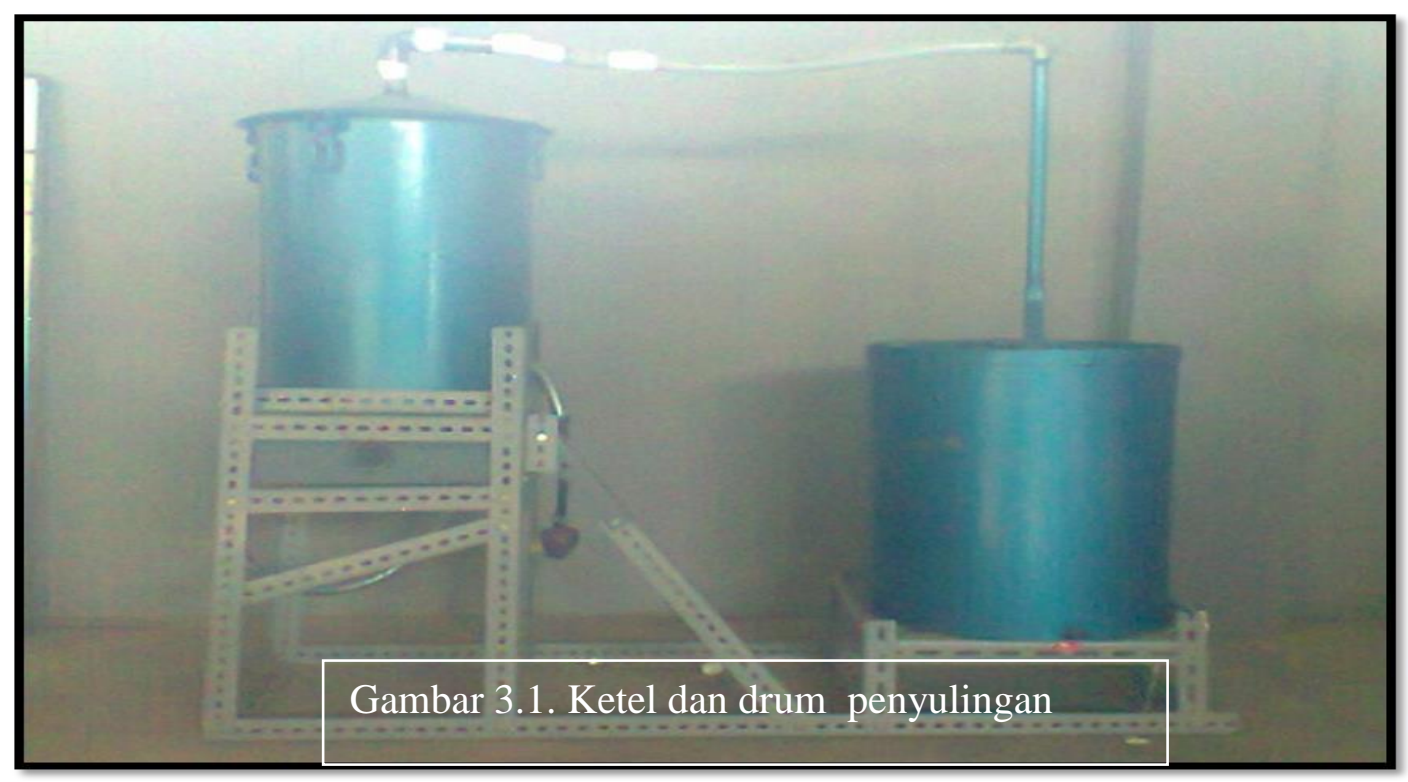


c) Setelah temperatur telah mencapai suhu $40^{\circ} \mathrm{C}$ maka ditambahkan Ragi tape sebanyak $2 \%$. Pencampuran ini bertujuan untuk meningkatkan aktivitas mikroba. Pencampuran ini ragi yang digunakan harus dilembutkan terlebih dahulu agar dapat bercampur dengan bubur ganyong.

d) Setelah selsai tutup rapat bak fermentasi, waktu proses fermentasi selama 7 hari atau seminggu.

\subsubsection{Proses Hilir}

a) Proses distilasi atau penyulingan. Pada waktu penyulingan suhu ketel harus dibawah $80^{\circ} \mathrm{C}$ untuk menghindari terjadi penguapan air. Karena titik didih etanol $78^{\circ} \mathrm{C}$.

b) Pada umumnya penyulingan ini hanya menghasilkan etanol yang memiliki kadar $75 \%$, untuk mendapatkan etanol yang berkadar $(97-99,5) \%$ maka harus dilakukan distilasi ulang.

\section{HASIL DAN PEMBAHASAN}

\subsection{Hasil Penelitian}

Dari hasil penelitian ini dapat diketahui :

1) Berat sebelum digiling : $44,5 \mathrm{~kg}$

2) Berat setelah digiling: $44 \mathrm{~kg}$

3) Berat pati: $8,3 \mathrm{~kg}$

4) Ampas umbi ganyong : $9 \mathrm{~kg}$

5) Bioetanol 4550 mililiter

6) Kandungan Air : $27 \mathrm{~kg}$
Tabel 3.1. Proses Liquifikasi dan sakarifikasi

\begin{tabular}{|l|c|c|l|}
\hline No & Waktu & Suhu & \multicolumn{1}{|c|}{ Keterangan } \\
\hline 1 & 106 menit & $105{ }^{\circ} \mathrm{C}$ & $\begin{array}{l}\text { temperatur } 105^{\circ} \mathrm{C} \text { dan } \\
\text { dipertahankan selama } 30 \text { menit. }\end{array}$ \\
\hline 2 & 136 menit & $95{ }^{\circ} \mathrm{C}$ & $\begin{array}{l}\text { temperatur diturunkan hingga } \\
95^{\circ} \mathrm{C} \text { dan dipertahankan selama } \\
75 \text { menit. }\end{array}$ \\
\hline 3 & 216 menit & $95{ }^{\circ} \mathrm{C}$ & $\begin{array}{l}\text { temperatur diturunkan dari } 95^{\circ} \mathrm{C} \\
\text { hingga mencapai } 40^{\circ} \mathrm{C} \text {, untuk } \\
\text { dilakukan proses fermentasi }\end{array}$ \\
\hline 4 & 516 menit $40{ }^{\circ} \mathrm{C}$ & $\begin{array}{l}\text { Suhu telah mencapai } 40^{\circ} \mathrm{C} \text { lalu } \\
\text { ditambah ragi untuk } \\
\text { difermentasi }\end{array}$ \\
\hline
\end{tabular}

Pada proses ini pemanasan di lakukan hingga temperatur $105{ }^{\circ} \mathrm{C}$. Selanjutnya temperatur diturunkan bertahap hingga mencapai suhu $40{ }^{\circ} \mathrm{C}$ lalu ditambahkan ragi atau yeast (Saccharomyces cereviseae) untuk difermentasikan, waktu yang dibutuhkan untuk menurunkan suhu hingga $40{ }^{\circ} \mathrm{C}$ selama \pm 5 jam.

b) Temperatur proses destilasi

Pada tahap penyulingan temperaturnya dijaga tidak melebihi $78^{\circ} \mathrm{C}$, hal ini untuk menghindari air juga ikut menguap, sehingga hasil bioetanol jadi lebih murni.

Tabel 4.2. Proses Penyulingan bioetanol

\begin{tabular}{|c|c|c|c|l|}
\hline No & $\begin{array}{c}\text { Waktu } \\
(\text { menit })\end{array}$ & $\begin{array}{c}\text { Suhu } \\
\left({ }^{\circ} \mathrm{C}\right)\end{array}$ & $\begin{array}{c}\text { Hasil } \\
(\mathrm{ml})\end{array}$ & \multicolumn{1}{|c|}{ Keterangan } \\
\hline 1 & 0 & 28 & - & $\begin{array}{l}\text { Penyalahan sumber api pada } \\
\text { pukul 08.45 }\end{array}$ \\
\hline 2 & 45 & 62 & - & $\begin{array}{l}\text { Pada menit ke 45 suhu telah } \\
\text { mencapai } 78^{\circ} \mathrm{C} \text {, dan api } \\
\text { diturunkan dan dijaga } \\
\text { konstan. }\end{array}$ \\
\hline 3 & 56 & 78 & 1 & $\begin{array}{l}\text { Pada menit ke 56, bioetanol } \\
\text { mulai menetes dan telah } \\
\text { produksi }\end{array}$ \\
\hline 6 & 1140 & 78 & $4550 \begin{array}{l}\text { Setelah waktu mencapai } \\
330 \text { menit, sumber api } \\
\text { dimatikan, penyulingan } \\
\text { pertama selesai }\end{array}$ \\
\hline
\end{tabular}

\subsubsection{Temperatur}

Temperatur Liquifikasi dan
Sakarifikasi

\subsection{Pembahasan}

\subsubsection{Kapasitas Produksi Ganyong}

Alat yang digunakan pada proses produksi bioetanol yaitu seperti : 
a) Tabung Ketel yang berfungsi untuk memanasi pati ganyong dengan volume 48 liter

b) Tabung Distilasi.

Tabung distilasi atau penyulingan yang digunakan untuk proses pendinginan uap bioetanol dengan volume 63 liter

c) Pipa penyulingan dengan diameter $3 / 4$ inch dan panjang $40 \mathrm{~cm}$

\subsubsection{Proses Pengolahan Umbi Ganyong}

Pada tahap liquifikasi dan sakarifikasi, pati direbus dalam ketel dan dicampur air, dengan ukuran banyaknya air tiga kali banyaknya pati, perebusan ini akan berbentuk bubur. Bubur umbi ganyong tersebut dipanaskan selama dua jam sehingga membentuk gel dengan suhu $105^{\circ} \mathrm{C}$ selama 30 menit, kemudian didinginkan sampai mencapai temperature $95^{\circ} \mathrm{C}$ yang diperkirakan memerlukan waktu sekitar 15 menit. Temperatur $\quad 95 \quad{ }^{\circ} \mathrm{C}$ tersebut dipertahankan selama 75 menit. Proses ini bertujuan untuk memecahkan rantai dekstrim menjadi glukosa. Setelah perebusan selesai Temperatur ketel diturunkan hingga $40{ }^{\circ} \mathrm{C}$ untuk melakukan proses fermentasi.

Fermentasi ini dilakukan setelah bubur ganyong telah mencapai temperatur 40 ${ }^{\circ} \mathrm{C}$, lalu tambahkan ragi sebanyak 0,2 $\%$ dari berat pati. Proses fermentasi ini dilakukan selama satu minggu dengan keadaan tertutup rapat. Tahap selanjutnya adalah proses penyulingan atau distilasi menggunakan media pendingin air.

Distilasi ini bertujuan untuk memisahkan alkohol dengan air dengan cara dipanaskan ketel dengan temperatur $\pm 78{ }^{\circ} \mathrm{C}$. Hal ini untuk meningkatkan proses penguapan alkohol. Alkohol yang menguap dialirkan kedalam pipa yang membentuk sepiral didalam tabung distilasi yang bertujuan agar uap tersebut menjadi cairan alkohol atau bioeatnol.

\subsubsection{Banyak Bioetanol Yang Dihasilkan}

Pada proses pemisahan pati dengan ampas ganyong diperoleh pati sebanyak 8,3 kg dan ampas sebanyak 9 $\mathrm{kg}$. Pati sebayak 8,3 $\mathrm{kg}$ dimasukan kedalam ketel dengan tambahan air sebayak 27 liter air dan dicampur hingga homogen, maka diperolah dari pencampuran keduanya sebanyak 35 liter, setelah dilakukan proses liquifikasi dan fermentasi volume menyusut hingga 34,5 liter bubur ganyong. Setelah proses penyulingan maka didapat minyak bioetanol sebanyak 4550 mililiter atau 4,55 liter.

Ada beberapa hal yang harus diperhatikan pada proses pengolahan bioetanol ini yaitu :

a) Terdapat bioetanol yang menguap dan tidak keluar melalui pipa penyulingan, tetapi hanya menempel di dalam ketel terutama pada kondisi ganyong hampir habis, sehingga hasil jadi tidak maksimal.

b) Kondisi alat yang digunakan juga akan mempengaruhi hasil akhir. Seperti dinding ketel dan pipa penyulingan terlalu tebal, hal ini jadi tidak efisien.

c) Adanya kebocoran dibagian tutup ketel, sehingga uap tidak sepenuhnya mengalir ke pipa dan terbuang keluar. 


\section{PENUTUP}

\subsection{Kesimpulan}

Dari hasil uraian di atas maka dapat disimpulkan :

a) Kapasitas alat produksi bioetanol yang digunakan.

- Volume tabung ketel yang digunakan yaitu 48 liter

- Volume tabung penyulingan yaitu 62 liter air pendingin.

b) Proses pembuatan bioetanol dengan beberapa tahapan, dari pemisahan pati terhadap ampas ganyong, proses liquifikasi, sakarifikasi, fermentasi, hingga penyulingan bioetanol.

c) Pada proses ini menggunakan bahan baku ganyong 44,5 kg menghasilkan pati sebanyak $8,3 \quad \mathrm{~kg}$ serta menghasilkan bioetanol sebanyak 4,55 liter.

\section{DAFTAR PUSTAKA}

Artikel non-personal, 20 Maret 2012, "Bahan Bakar Etanol", Wikipedia Bahasa Indonesia. (online) http://id.wikipedia.org/wiki/Bahan bakar_etanol. diakses 10 April 2012.

Annida, $30 \quad$ Desember 2011 "KandunganGizi Serta NutrisiGanyong". (online) http://tepungganyong.annida.net/?p= 26 di akses tanggal 15 Maret 2012

Bukabi, 2 Febuari 2009, "Umbi Ganyong", (online) http://bukabi.wordpress.com/2009/0 2/02/umbi-ganyong/ diakses tanggal 15 Maret 2012.

Chadidjah, Siti dan Wiyoto. “ Konsep Teknologi Renewable Energi", Jakarta. Genta Pustaka. 2011
Debioka, 05 Desember 2009 "Green Energi Pembuatan Bioetanol dari Umbi Ganyong" (online) http://biokim.wordpress.com/2009/1 2/05/green-energy-pembuatanbiotanol-dari-umbi-ganyong/ diakses tanggal 09 Juni 2012

Djokodetyardjo, “Ketel Uap", Jakarta, Paradnya Paramita. 1993.

Richana, Nur. "Bioetanol bahan baku, Teknologi, Produksi, dan Pengendalian Mutu". Bandung. Nuansa Cendikia. 2011.

Ruhyat, Nanang."Pembuatan Prototype Alat Destilasi Minyak Atsiri Skala Industri" Universitas Mercu Buana.2009

Tim Pengembang BBN, "BBN Bahan Bakar Nabati, Bahan Bakar Alternatif dari Tumbuhan sebagai Minyak Bumi dan Gas", Depok. Penebar Swadaya. 2008 